\title{
Perceptions, Practices and Challenges of Oromo Gabbara Marriage System: The Case of Some Selected Woredas of Bale and West Arsi Zones
}

\author{
Muktar Ahmed* \\ Department of English Language and Literature, College of Social Sciences and Humanities, Madda Walabu \\ University, Ehtiopia \\ Sufyan Alo Dalu Abbuni \\ Department of Afaan Oromo and Literature, College of Social Sciences and Humanities Madda Walabu \\ University, Ethiopia. \\ Issa Hasan \\ Department ofSociology, College of Social Sciences and Humanities Madda Walabu University, \\ Ethiopia
}

\begin{abstract}
The main objective of this study was to investigate perceptions, practices and Challenges of Oromo Gabbaraa Marriage system in the case of some selected woredas of Bale zone and West Arsi zone. To meet the objectives, ethnography research design was mainly employed. A total of 12 kebeles (three kebeles from each woreda) were selected purposively. In the study, 60 couples and 36 elders were involved using snowball sampling technique, and 8 Gadaa leaders as well as 12 religious leaders were chosen purposively. In general, 116 participants were involved in the study. Four instruments of data collection (interview, FGD and non-participant observation) were used. Through semi-structured interview and focused group discussion, the data were collected from elders, couples, Gada leaders and religious leaders. Four wedding ceremonies through participant observation were also observed. Then, the collected data were analyzed and discussed qualitatively under different headings according to their concepts. The results show that Gada leaders, religious leaders, elders and couples have negative perceptions towards the cultural, social, economic, and psychological impacts of this marriage system since it deviates from cultural outlook. The study also shows that gabbara marriage is being practiced mostly in the study area with high dowries'. As the results indicate, as dowry has been being increased over time, it is increasing migration (which is a global issue) of youngsters for collecting money from abroad, particularly, in Shalla and Shashemene districts. As a result, it has been affecting negatively the life of couples socially, culturally, and economically. Moreover, couples and their family and society as a whole have been being challenged in different aspects by the high amount of gabbara. Hence, to minimize this adapted and deviated dowry practices, the concerned stake holders like cultural and tourism officers and Gada leaders, religious leaders, elders and youngsters should work hand-in-hand.
\end{abstract}

Key terms: Perceptions, Practices, Challenges, Gabbaraa, Marriage system, Oromo

DOI: $10.7176 / \mathrm{JCSD} / 48-04$

Publication date:May $31^{\text {st }} 2019$

\section{Introduction}

\subsection{Background of the Study}

Naturally, marriage is an exceptional association dissimilar with all others that should be performed based on the biological difference as a man and a woman to the generation of new life. Marriage plays an important role in social perspectives, and it is an institution that unites a man and a woman in a permissible and, indeed, much encourages relationship. Then, the couples start their journey together through reproducing children in society and live in its true spirit of culture and develop the character and behavior of that society (Abdul-hai, 2012).

Obviously in Ethiopia, there are number of ethnic groups with diverse ways of cultural life. Among the largest ethnic group in the country, Oromo community build affectionate family bond through cultural marriages and consider it as a respectable natural and cultural practice (Mammo, 2013). Among its indigenous cultures, the Oromo see marriage as one of the most important ceremonies. There are three things Oromos talk about in life: birth, marriage, and death. These are the events that add to or take away from the family (Gemmechu and Assefa, 2006). In addition, Oromo believes that one's chastity, honor and dignity are preserved through marriage. Moreover, Oromo gives special place for marriage because it does not only a way of life passage, but it also portrays admiration. 


\subsection{Statement of the Problem}

Culturally, Oromo particularly Arsi has different marriage systems namely Baal-tokkee (Gabbaraa), Walgara, Membeetoo, Hawii, Mata-dibaa (short marriage system), Adda-Baanaa, Aseennaa (interance), Dhaala (inheritance), Sabbat Marii, Gursummeettii and some others. The Oromo has been practicing these marriage systems in various ways in line with its culture and customs (Hussein, 2000).

As the existing reality, Gabbaraa marriage system is one of the most being practiced marriage system over the rests among Arsi Oromo. This marriage system is performed through both spouses' will and consent where relatives are also invited. Historically, from the Arsi Oromo customary marriage systems, this marriage has been being increased after the ongoing decline of Baal-tokkee marriage system (a marriage system that made with the consent of both spouces) though they have similarities in marrying new bride (Hussein, 2000). Nevertheless, Baal-tokkee marriage system was being practiced especially among Arsi Oromo with a minimum gift as Gabbaraa (dowry). Gradually, Gabbaraa marriage emerged and became dominant over Baal-tokkee marriage system seeming to have cultural outlook particularly in West Arsi (ibid). Then, it has been being sustained with high Gabbaraa (formal payments of money and cattle or other property) to the bride's family; it seems there are imbalance perceptions, practices and challenges among this Oromo's societies in real situations.

Up till now, the amount of dowry in Gabbaraa marriage is being incremented from time to time like buying and selling commodities in the market. Hussein (2000:115) states it in Afaan Oromo from economic view point as "fuudha Gabbaraa jechuun, intala takka horiin bitachuu jechuun addaan ka fagaatuu miti". This implies that Gabbaraa marriage means that it does not far from buying ones girl by property or money. For the anxiety, some youngsters started to perform marriage by their interest without prior understanding of their family. These may have two impacts. The first one is a quarrel between bride's family and groom's family; and also between both spouses and their families; because of irrespective duties they made. The second is the impacts on the indigenous culture of wedding. Performing marriage in that manner may good for spouses from economic perspective, but, in other side, they are deviating from indigenous culture of wedding and adapting the new culture.

Relatively, no detailed studies have carriedout on similar topic to this study. But, two other researches were conducted on the types of custom marriage system practiced in North Wollega and cultural wedding music of West Arsi, Oromia. Particularly, Gemechu and Assefa (2006) have conducted their research on marriage ceremonies and types of marriage systems practiced among Gidda Oromo, Northern Wollega. The focuses of these researchers were on the identification of custom marriage systems of Gidda Oromo. Additionally, Leila Qashu (2009) was analyzing the Wedding Music of Arsi Oromo Society. She emphasized on the thematic analysis of wedding music of Arsi Oromo by focusing on three main groups of actors that each has different social responsibilities and musical repertoires: men, women and youths. Her intention was only to see what kinds of music songs take place during the wedding ceremonies of that society. As far as the survey of conducted researches concerned, the present study is different from each other.

Thus, this study was conducted to investigate the perceptions, practices and challenges of Gabbaraa marriage system among West Arsi and Bale Oromo societies. Moreover, the study was undertaken to meet the following specific objectives.

\subsection{Objectives of the Study}

The specific objectives are stated in the following way.

1. To identify perceptions of Oromo married couples, elders, Gada leaders, cultural experts and religious leaders of West Arsi and Bale zones towards the historical development of Gabbaraa marriage system.

2. To examine the typical practices of Gabbara marriage over time among societies.

3. To investigate the challenges of this marriage system on the socio-economic and cultural aspects of these Oromo societies.

4. To find out the factors those contribute for the challenges of this marriage system on the mentioned Oromo societies.

\section{Literature Review}

Conceptualy, marriage is an institution that unites a man and woman in a permissible relationship. Married love is a unique form of love between a man and woman which has a special benefit for the whole society. Even though the process is different from each other, male and women relationship is a natural rule that implemented all over the world (Mammo, 2012).

Oromo seeks to create durable bases for relationship within the family, which is the building block of society. When each of these blocks is firmly placed, the social structure of the society rests on a strong foundation. Social studies contribute towards clarifying the positions of various marriages on gender-related injunctions, justifying concepts and interpreting texts that address human sexuality. Human males and females are each endowed with sets of features some of which are largely identical, while others are distinguishing 
characteristics (Abdul-hai, 2012).

Traditionally, in the custom of Oromo, spouse safeguards from the unlawful sexual intercourse; this is the goal of marriage (Mammo, 2012).The sexual cohabitation (intercourse) between a man and a woman is such an act which converges, the personality of both on one point. Moreover, one of the objectives of marriage is to protect both spouses against indulgence in unlawful sexual practices that may lead to corruption and immoral acts in the society (Abdul- Hai, 2012). Similarly, Oromo believes that neglecting marriage or rejecting it regarded as a denial of all the normal human behaviors and poor code of social ethics (Mammo, 2013).

According to Hussein (2000), there are about ten cultural marriage systems mainly in Arsi Oromo society, namely 'Hoohoyyoo (Naqata), Walgara, Buttaa, Aseennaa, Hawii, Addabaana, Biidha-baasa/Irradhaaba, Dhaalaa and Gursummeettii. The above mentioned are types of marriage depending on the way their processes of ceremonial procedure (Hussein, 2000). Let us see some of them in the following way.

\section{Research Methodology and Methods 3.1 Study Areas}

The study was conducted in Bale and West Arsi zones of Oromia region. From both zones the study covered 4 woredas. In this manner, from Bale zone Sinana and Rayitu whereas from West Arsi zone Shashamene and Shalla woredas were selected.

Geographically, Bale is bordered on the south by the Ganale Dorya River which separates it from Guji, on the west by the West Arsi Zone, on the north by Arsi, on the northeast by the Shebelle River which separates it from West Hararghe and East Hararghe, and on the east by the Somali Region. All woredas under study of Bale zone are found to different directions from the capital of Bale zone; i.e. Robe town.

Besides, West Arsi or in Afan Oromo 'Arsii Lixaa/Dhihaa' is one of the zones of the Oromia Region in Ethiopia. This zone is named after a subgroup of the Oromo, who inhabit it. West Arsi was formed of woredas which included to Arsi, Bale and East Shewa zones. Similarly, two woredas were selected from West Arsi zone namely Shashemene and Shalla which have different distances from the capital of the zone; i.e. Shashemene town.

\subsection{Research Design}

To meet the suggested objectives, the researchers mainly employed ethnography research design for it can guide them to understand larger-scale, macro-level phenomena, cultural practices over time; particularly, how Gabbaraa form of marriage brought a major cultural/societal changeover time in Arsi and Bale and what resulted from the change. In addition, quantitative method was used as a supplementary method since the issue at the hand was complex. The triangulation method is used when combinations of the two forms of inquiry are used (Dawson, 2002: 23) and they can build the unique strengths of each method and offset the weaknesses of each. For this case, qualitative methods were used as major tools like in-depth interview, focused group discussions and observation whereas questionnaire method was used as supplementary tool.

\subsection{Sample Size and Sampling Technique}

As a sample, the total of four districts from Bale (Sinana and Rayitu) and West Arsi (Shashemene and Shalla) zones were involved purposively in the study; because of Gabbara marriage is being practiced there. Almost all the typical manner of practicing this Gabbara marriage is more related in these zones. Three kebeles were selected from each woreda of both zones purposively which were 12 in number. The study involved married couples since 2000 E.C because the gabbara amount has been increased gradually from this year (Hussein, 2000). As participants, elders, Gadaa leaders/officials, religious leaders and cultural experts were selected. In this regard, 60 married couples (five of them from each kebele) and 36 elders (three elders from each kebele) were selected using snowball sampling technique. Similarly, 8 Gada leaders and 12 religious leaders (two of them) were selected from each woreda purposively. Totally, 116 participants were involved in the study.

\subsection{Data Collection Tools}

The revelant data was collected using three tools of data collection (interview, Focused Group Discussion, and non-participant observation) from couples, elders, Gada leaders and religious leaders. The researchers employed the semi-structured interview, and collected data from 24 married couples, 12 elders, 8 Gada leaders, and 12 religious. To make clear the discussion, the interview was held in Afan Oromo.

Focus group discussion was held with 48 couples and 24 elders arranging them into 12 groups in their respective kebeles. This means, 6 members ( 4 married couples and 2 elders) from the same kebele grouped together since the kebeles are from each other. During discussion, the participants' ideas were recorded using tape recorder, and necessary short notes were also taken. The discussion of the participants was held by Afaan Oromo.

As observation was also conducted, for it is used to draw the direct evidence of the eye witness events 
(Denscombe, 2003:192). Thus, to get more relevant information, the researchers observed four (4) wedding ceremonies of Gabbaraa marriage system in the study sites. These had done for getting clear picture of what the actual Gabbaraa marriage system looked like, and the emphasis was given to capture the experience of members of the society. To this end, participant observations were arranged based on the objectives of the study.

Finally, the collected data, as the above mentioned procedures, was transcribed thematically and analzed verbally and discussed deliberately under different headings.

\section{Data Analysis and Interepretation}

This chapter consisted analysis and interpretation of data collected through interview, focused group discussion and observation, and the result that was discussed as follows.

\subsection{Analysis of Data Collected through Interview and Focused Group Discussion 4.1.1 Types of Cultural Marriage Systems Known in Bale Zone and West Arsi Zone}

The following are the types of marriage systems practiced in the two zones (West Arsi and Bale). The data obtained from elder respondents show that there are about nine ways of getting marriage systems. These are explained as follows.

1. Seenee: - this marriage system is a system that long live with the society and widely known and it is the most formal.

2. Hawii:- is a marriage system that the boy or/and his friends convince her without discussing with other her families and her clan members. It is well known in West Arsi zone, and it is usually performed in order not to pay a number of heads of cattle, materials and money to the girl's family.

3. Abduction (Buttaa): is one of the marriage systems found in Bale and West Arsi zone. It is a marriage system performed occasionally and is gradually being ignored. This marriage system depends on the only interest of the boy or the male who prefers to marry her. When he loves and wants her to marry, he may ask her for marriage and if she refused to agree he calls his 'saddeetaa' means his intimate friends about eight or more in number. Then, he attends her footsteps and takes her forcefully. It is shameful to give her back though her families tried to survive her. In general, this marriage system is performed forcefully by the boy's side family's interest only and it is a harmful.

4. Walgara (Exchange):- is a marriage system which is happened between the two clan families by changing their two girls. Specially this marriage system was more common in West Arsi and is gradually being ignored by the society because of sometimes unbalanced life comfort of the two married girls. This marriage system also follows a formal process that the both sides families interest as a Seenee mentioned above.

5. Aseennaa: - this marriage system occasionally occurred in these two zones. Aseennaa marriage system, which is the opposite of Buttaa (Abduction), only depends on the interest of the girl who loves or prefers the boy to marry. In this case, the girl who wants to marry him will go bridegroom's home family having a cultural unmarried girl symbol stick (siinqee), garbuu (barley), scatters hiddii (solanaceous fruit) and mijuu (a full of viscous milk). Finally, the agreement made between the boy and her families after many cultural procedures are made by elders of both parties.

6. Cabsaa (Biidhaa Baasa):- is a marriage system undertaken without the love of the bride and her families. The word 'Cabsaa' means 'accidental/impromptu action'. The boy's families or members of wedding ceremony accidentally arrive at the girl's family home because of missing of the one they previously intended to marry from that family or clan members (gosa sanirraa). This marriage system is also implemented when the family of the girl wants to change their ideas not to marry to him. Her families cannot refuse to give because they afraid of elders' curse.

7. Dhaala: - is known in both zones. Dhaala literally means "inheritance". Still, it is being practiced among Oromo people. Though its starting is unknown, it is taken place when ones husband is died from his wife due to different reasons the bridegroom's family make her to marry his elder brother or younger brother of her decreased husband. The reason behind this is, to reserve the dead man's children within the family and save them from mistreatment by the stepfather to whom the widow may marry. Besides, the dead man's family takes the responsibility of safeguarding his wealthy to protect the woman not to marry other person with his wealthy.

8. Hayyii: is particularly popular in Bale zone. It is performed without willingness of both bride and her family. In its procedures, the boy identifies the girl whom he wants to marry first. Second, he tells to her brother. After he makes negotiation with her brother, he starts to wait for that girl around the beach of a river being with her brother. Third, they get her to any house they need with/out her comforts. After that, the owner of that house goes to bridegroom's father with other elders and tells him that his boy has taken a daughter of other person. Father of that boy also gathers other elders and sends them to bride's family for negotiation (araaraaf). The preferred elders then go to the house of bride's family and say to them "the 
son of mr.Y handles your daughter miss. X; make family for us" ("intala teessan ebaluun mucaan ebaluu harkatti qabateeraa; nu warroonfadhaa". Finally, they negotiate and being family in-law (soddoomuu) in both cases.

9. Gabbara: is one of the marriage systems recently known and being practiced in West Arsi and Bale zones. Its implementation is held with different gifts of bridegroom and his family for bride's family. Since Gabbaraa marriage is the major issue of this study, it is discussed briefly under different headings as follows.

\subsubsection{Definitions of Gabbaraa}

According to the respondents, Gabbaraa means gifts provided by bridegroom or by his family or with their relatives for bride's family as a gift or support. These dowries include different properties (living and non-living things). Not only gifts but also the bridegroom serves them in different perspectives.

The basic reasons behind these gifts are: to worroonfachuu (to form respectful family -in-law). Besides, the bridegroom adopts the sense of mother-father-in-law (aayyaa-aabbaa), and he continuous living with his wife and her family honorly and lovely. According to the elders' reflections of West Arsi zone, dowry (Gabbaraa) of father-in-law does not come to end at once. This is happened because of its wider aspect that it includes different service provided by bridegroom for family-in-law. Hence, when they want to express Gabbaraa, they use the proverb "gabbarri soddaa hin dhumu" or "Father's in-law dowry does not come to end".

\subsubsection{Historical Development of Gabbaraa Marriage System}

Historically, the previous Gabbaraa marriage had close relationship with a kind of marriage called hohoyyoo. According to the conducted survey and the obtained information from respondents, Gabbaraa was started originally among Arsi Oromo by the gifts of only two cattle which were one heifer and bull (raadaa fi jibicha) and two blankets (wayaa lama) given for bride's family. From these gifts, the two cattle and the two blankets (Wayaan lamaan) were prearranged for fathers and mothers. Al though the exact starting time of Gabbaraa is not known clearly among the people, the reflections of respondents revealed that the gifts were highly related to cultural sense to advocate mother-father (aayyaa-aabbaa) instance.

According to the evidence, this marriage (Gabbaraa) has been being increased highly from 2000 E.C Hussein (2000). He wrote the book entitled "Seera Fuudha Oromoo Arsii" with detail explanations on the raise of Gabbaraa marriage. The increment of Gabbaraa is being high in the West Arsi zone particularly Shalla woreda took the first rank than others.

In the long run, the gabbaraa (dowry) has been being developed progressively due to the following factors. These are:

* The impact of globalization lead the community unable to aloofing their indigenous culture. In the practice, they do not care much for cultural materials, but they need more recent and technology related materials where cultural materials are not being focused.

* people's perceptions of marrying with high dowry and increase need of money and cumulating wealthy

* sense of competition like my daughter should be married more than others,

* showing their status among community;

* upholding overhearing;

* portraying superiority in the community and

* Developing the perception of their married daughter can be kept smoothly by her husband due to large amount of dowries.

Similarly in Rayitu woreda of Bale zone, Gabbaraa was being practiced highly for the last five years (before 2005 E.C). During that time, Gabbaraa was divided into two types. These are: waan namarra deemaa (things go on human) and waan lafarra deemaa (things go on earth). These means, things go on human are coffee bean and mother's cloth. It is said to be that coffee bean is received at hand and drunk by bride's family while mother's cloth is worn by mother in-law. So, these things are portrayed and go with human. The second form of Gabbaraa is things go on earth which are called shanan aadee (raaddan shanan) (five heifers). These five heifers should not be with the broken teeth and have no pregnancies. In the gift procedures, those heifers are given to the bride's mother, father, brother, father's elder brother and uncle. Besides, if the proposed daughter to marry is the last or the only daughter of her mother, a donkey is given to mother's in-law by a groom for transport purposes. In a nut shell, the amount of Gabbara is being decreased in Bale zone particularly in Rayitu district since 2005 E.C with consensus of society. In contrast, it has been being increased in West Arsi zone predominantly in Shalla woreda. Moreover, Gabbaraa has been exposing many people for high expenditures and instability of their life and it is became hatted among the most society.

\subsubsection{The Perceptions on the Raising of Gabbaraa (Dowry) of Gabbaraa Marriage System}

As elder respondents said, the society has different perspective to the Gabbaraa marriage system as total because the system has lost its original behavior and erased its basic societal norms. Accordingly, the respondents' responses have multidimensional which is analyzed below.

The requested elders responded as follows that gabbaraa: 
* was originally performed with respectful and has not harmful

* Strengthen the love of both (bride's and groom's) families.

* Form a smooth relation among the couples as well as both families in the past which is opposite of current.

\# But today, it bacame the source of income for many people.

\# People are asking much money to give one girl to somebody who wants to marry.

Islam religion followers' scholars also responded that one should give a minimum one heifer or may any other materials like a ring or clothes to her but not to her families as the cultural Gabbaraa dowry.

From the view of women though there are different perceptions about the Gabbaraa dowry, most of the girls believed as they would get a better concern and a good value from their husband if he west much amounts of cost to marry her. Their idea was explained as below.

....intalli takka yemmuu bultii ijaarattu Gabbaramtee heerumuu qabdi. Sababni Gabbaramuu qabduufis, inni duraa mucaan intala gabbaree fundhe baasii guddaa itti baasee fuudhe waan taheef, salphaatti ilaaluun itti boonee ari'uuf maallaqni waan garaa isa nyaatuuf ni bulfata. Inni biraa immoo, warri gurbaas maallaqa guddaa waan itti baasaniif kabajanii bulfatu. Faayidaan biraa, gosa itti heerumte keessatti intala baasii hangana gahuun heerumte jechuun warra kaan caalaa ilaalcha addaa kennuuf. Intalti kan yaaddu, ani intala eenyuutii gadi, maaliif Gabbara xiqqaan heeruma jechuun of gaafatti; hiriyoota ofii waliin mari'atti. Ee..em haala kanaan yaanni dorgommii shamarran gidduutti guddachaa jiruudha. (Maanguddootaa, abbootii amantii fi gadaa fi dargaggoota aanaalee iddatteeffaman, Caamsaa, 2009)

The idea explained above is in short most unmarried girls think that to be respected and realized as they are more attractive than the others, they approve depending on the amount of Gabbaraa dowry brought for her families. She suspects that she will not get a good attention as a wife from her husband if he would get her without giving Gabbaraa (dowry) or give a small amount. Other than these, to be honored beside their husband, his family, relatives and neighbors and to a win sense of competition "Whom I inferior to?" some females have good perceptions towards high amount of dowry in Gabbaraa marriage system.

On the other hand, some youngsters afraid to get married; some moves to abroad to collect amounts of money for the dowry, and some face a challenges of giving back a borrowed money and cattle during the marriage. As a result, they will finish what they have in their hands, and sometimes they will divorce the marriage. Thus, the youngsters seriously criticized the Gabbaraa marriage system as it is very harmful.

In general, as respondents of this research, the Gabbaraa (dowry) that is taken in different dimensions for the girl's family leads the couples to bad poverty life. In contrast, there are still individuals that are using it as illegal slavery trade marketing.

\subsubsection{The Current Status of Gabbaraa Marriage System}

Here, the status of this marriage system has been analyzed regarding the attitude towards it and the current practice from the four woredas of the two zones.

From the very beginning of Oromo culture, Gabbaraa marriage system includes assisting, and giving all appropriate respects for her father, fathers in-law, mother and mothers in-law, whereas a days it became a trade. Elders' include the reasons of that as follow:

$>$ When selecting the one to marry, his family first focus to her family's wealth rather than personal quality because to assure as they can give back a good dowries with her.

$>$ Her family also has no concern of the girl's future life rather than recent profits.

$>$ Given properties are not cultural materials and represent cultural symbols

$>$ The process of its practice did not in the way of cultural values and ethics

$>$ Due to the rise of gabbaraa, divorse, adultery practice, unwanted preginancy, health problems, social crisis, bad behaivours, etc are being developed among the society and it is affecting youngsters negatively.

$>$ The perceptions of Oromo community's towards Gabbaraa marriage is being improved to some extent particularly in Rayitu woreda of Bale zone.

$>$ People's awareness has been developed on the challenges of Gabbara in Rayitu woreda and they made a consent that any person does not allowed to marry through Gabbaraa from 2005 E.C.

$>$ Elders and Gada leaders played their role to avoid totally the practice of high Gabbaraa.

$>$ In contrast, Gabbaraa is being continued highly in Shalla woreda of West Arsi zone.

$>$ Negatively, the richest people particularly dislike Gabbaraa marriage as not to be vanished or changed to the indigenous culture since most of them consider it as a great source of income in this woreda.

For instance, in West Arsi zone, bride's father is given clothes and 10-40 cattle as per amount of cattle brought by bridegroom. In addition to that, 10,000 and 80,000 - 100,000 Ethiopian Birr is allotted for wedding ceremony and for the respect of father- in law respectively. Motor-cycle and cultural dinks (wine) with 80,000 
birr or ten containers of honey are given to bride's family as additional dowry.

Hence, respondents anticipate that Gabbaraa marriage can pose different challenges on couples, their families and societies as a whole when it will continue to present with the same circumstances.

\subsubsection{Challenges of Gabbaraa Marriage System}

In case of practice, there are great differences among other marriage systems and Gabbaraa marriage. A gift of dowry in others marriage systems is few whereas in Gabbaraa marriage system much dowry should be given for bride's family with a little consideration of groom's economic status. Hussein (2000:115) states it in Afaan Oromo from economic view point as "fuudha Gabbaraa jechuun, intala takka horiin bitachuu jechuun addaan ka fagaatuu miti". This version implies that, Gabbaraa marriage means that it does not far from buying ones girl by property or money. This marriage is triggering the following major challenges on couples, families and societies as a whole particularly in West arsi zone. These are:

* Deviating from the form of cultural practice to modern wedding ceremony.

* Posing economic difficulties on the life of couples, -bride-groom.

* Decreasing the relationship of couples, family in-law, and society in general for worrying one another by the case of dowry.

* Exposing married couples for unnecessary expenditure and left without basic needs of life,

* Letting bridegroom for large amount of money deduction.

* Causing most of youngisters for migration to abroad countries to collect money. Besides, they have sold properties at their hands like oxen and apportioned farming lands yearly or for a long period of time which exposed them for poorness.

* Exposing youngsters for bad habits like adultery practice and illegal marriage which can increase divorce, sextually transmitted diseases, unwanted preginancy, health problems, social, economic and psychological risks on individuals in particular and society in general.

* Causing negative impacts in creating good bonds between couples, their families and among the whole societies.

The following sample records of respondents elaborate more the impacts of Gabbaraa marriage. ... sababa baasii humnaa olitiin intalaa fi gurbaan waan ittiin waliin jiraatan dhabuurraa, akkasumas gurbaan 'sababa kan kee waan qabu fixadhe' jechuudhaan waljibbiinsi jidduu isaaniitti uumamuu danda'a. Inni biraa, baasiin gama maatii gurbaatiin dursa bahee fi kan warri intalaa geegawoo kennan walmadaaluu yoo baate, maatiin lamaan addaan cituu danda'u. Itti dabalees, firoottan, ollaa, hawaasaa fi warri intalaa gaafa qarshiin Gabbaraa hiramu namoonni qarshicha Gabbara seeraan alaa fudhachuu yoo didan walitti mufii uuma. Kana malees, abbaan intalaa yoo waan inni jedhe gurbaan fiduufii dadhabe, intala san yoo dhibamtes hin gaafatu; akka isiin qe'ee warra abbaa isii dhuftus hin hayyamaniifi. Walumaa galatti, walitti bu'iinsi kallattii adda addaatiin baay'achuu (Odeef-kennitoota Aanaalee Shaashamannee fi Shaallaa 2009).

The above text of Afaan Oromo text shows that the expenses of Gabbaraa beyond the groom's economy can pose challenges on the couples future life, create complain between them, and their families; particularly, when there is imbalance between groom's gifts for bride's family and cattle or other properties given back to him from them. Besides, when the groom does not give the requested Gabbaraa (dowries) family in-law, bride's father does not visit couples even when his daughter is sick he never asks her.

Gabbaraa marriage is a marriage that has different social, economic and psychological challenges on Oromo communities' of the selected study areas.

\section{a. Social Challenges:}

Due to the raise of Gabbara, disagreement is being created among couples, bridegroom and his family-in-law; between bride and her husband's family and between both families. It develops dishonoring, disliking, disregarding and neglecting among them due to the increment of dowry (Gabbaraa). Moreover, bad practices like adultery, unwanted preginancy, divorse, sexually transmitted diseases etc. are being adabted in the society. The conflict of families, the couples, the bridegroom and in-laws, the bride and her-in-laws, tribal conflict are some of the major social challenges.

\section{b. The economic challenges are:}

When the bridegroom and his family are requested dowry (Gabbaraa) beyond their economic status, they are forced involuntary to sell materials at their house or loaned money from others to be escaped from an ashamed and backbiting of others when the bridegroom is not in a position to afford the payment asked by the bride's family he will resort to selling some of the property he has like land, house, house hold goods and taking credit money. The result of this is very serious for the bridegroom, as some of the married man will leave the country in search of money. After the wedding, the groom left bare hands and he tries to migrate outside to get money. In these procedures, he may pass over the sea or be a meal of fish or crocodile. The challenges that gabbara marriage system is imposing in economic aspect is summarized in the following table. 
Table 1: Properties given to bride's family members.

\begin{tabular}{|c|c|c|c|}
\hline $\begin{array}{l}\text { In West } \\
\text { Arsi zone }\end{array}$ & Properties & In Bale zone & Properties \\
\hline $\begin{array}{l}\text { For } \\
\text { bride's } \\
\text { father's }\end{array}$ & $\begin{array}{l}\checkmark \quad \text { different clothes like: blanket, 'gabi', } \\
\checkmark \quad \text { complete clothes, } \\
\checkmark \quad \text { For the wedding ceremony } 10,000 \\
\text { birr, } \\
\checkmark \quad \text { For what is called father's seat } \\
\checkmark \text { (Barcumaa Abbaa) 80,000-100,000. } \\
\checkmark \quad \text { Motor cycle if there } \\
\checkmark \quad \text { Honey for 'daadhii' }\end{array}$ & $\begin{array}{l}\text { For bride's } \\
\text { father }\end{array}$ & $\begin{array}{l}\checkmark \text { weapons, the father or the } \\
\text { elder son take them (as the } \\
\text { Rayitu Woreda respondents) } \\
\checkmark \quad \text { more than } 10 \text { Cattles and } \\
\text { camels } \\
\checkmark \text { money } \\
\checkmark \text { different clothes }\end{array}$ \\
\hline $\begin{array}{l}\text { For } \\
\text { bride's } \\
\text { mother's }\end{array}$ & $\begin{array}{llll}\checkmark & \text { Different clothes like dress and } \\
& \text { blanket } \\
\checkmark & \text { Bed with clothes } \\
\checkmark & \text { Mother's cow }\end{array}$ & $\begin{array}{l}\text { For bride's } \\
\text { mother's }\end{array}$ & $\begin{array}{ll}\checkmark & \text { different clothes and cows are } \\
\text { given to the mother } \\
\checkmark & \text { blankets } \\
\checkmark & \text { in Rayitu Woreda, if the bride } \\
\text { is the last or only daughter for } \\
\text { a family, a donkey is also } \\
\text { given for the bride's mother } \\
\text { for transportation purpose. }\end{array}$ \\
\hline $\begin{array}{l}\text { For } \\
\text { bride's } \\
\text { brother }\end{array}$ & $\begin{array}{ll}\checkmark & \text { Different clothes } \\
\checkmark & \text { Motor cycle or bicycle } \\
\checkmark & \text { House hold goods like TV, } \\
& \text { refrigerator etc. }\end{array}$ & $\begin{array}{l}\text { For bride's } \\
\text { brother }\end{array}$ & $\begin{array}{l}\checkmark \text { calf } \\
\checkmark \quad \text { a gun if there is any, it is } \\
\text { given to the bride's elder } \\
\text { brother. } \\
\checkmark \quad \text { Based on the number of cattle } \\
\text { the bridegroom has brought a } \\
\text { portion will also be given to } \\
\text { the bride elder brother. }\end{array}$ \\
\hline
\end{tabular}

c. Psychological shock

Psychologically, different people faced problems from this aspect.

$\checkmark \quad$ When the bridegroom could not pay back the money he borrowed from bank or people this exposes him for psychological problem.

$\checkmark \quad$ When people (groom, groom's family and their relatives) are unable to pay dowry decided by bride's family and their relatives.

$\checkmark \quad$ Feeling an ashamed due to difficulty to payback the loaned money from bank, their relatives and bridegroom's friends in Gabbaraa marriage system.

$\checkmark \quad$ The bridegroom faced difficulty of leading family and taking responsibility of household after the wedding ceremony and experience inferiority of his friends.

Therefore, as dowry (Gabbaraa) is being increased in these circumstances, the acceptance of Gabbaraa marriage system become distasting among the society.

\subsubsection{Major Factors Contributed for the Challenges of Gabbara Marriage System}

As we have discussed in the historical development of Gabbaraa marriage system, it has not been developed at once, rather than being developed gradually due to different factors. These factors contributed different roles directly or indirectly for the challenges of the current gabbaraa marriage. The following are among the factors contributed for the challenges of gabbaraa.

* The negative effect of globalization on the indigenous culture

* Lack of awareness towards the gradual development of gabbaraa marriage challenges.

* Sense of competition among societies in practicing gabbaraa marriage with high dowry.

* High consideration of gabbaraa as a great source of income

* Perceptions of most females on the challenges of gabbaraa as a positive.

Generally, it can be concluded from the data gathered from the the obtained data that the Gabbaraa Marriage system:

$>$ Is one of the age-old Oromo Cultural marriage systems of this study, its harmful effects outweigh its positive sides.

$>$ The number of people who can get married through this system cannot be expected to increase because of the problems associated with it.

$>$ It cannot in any way show the status of both the bridegroom and bride's family in the society.

$>$ It is the cause for other bad cultural practices like rape, abduction, fornication, and adultery.

$>$ Exposes both the bridegroom's family and the bride's family for unwanted expenditure. This is more so 
with the economy of the bridegroom.

$>$ If it continues to be practiced, it can create a lot of problems in the life of all the people involved in it.

\subsection{Analysis of Data Gained by Observations}

Under this topic the data obtained by observations are analyzed clearly. Some ceremonies of Gabbaraa marriage system were observed by the researchers those were taken in the study areas and presented as follows.

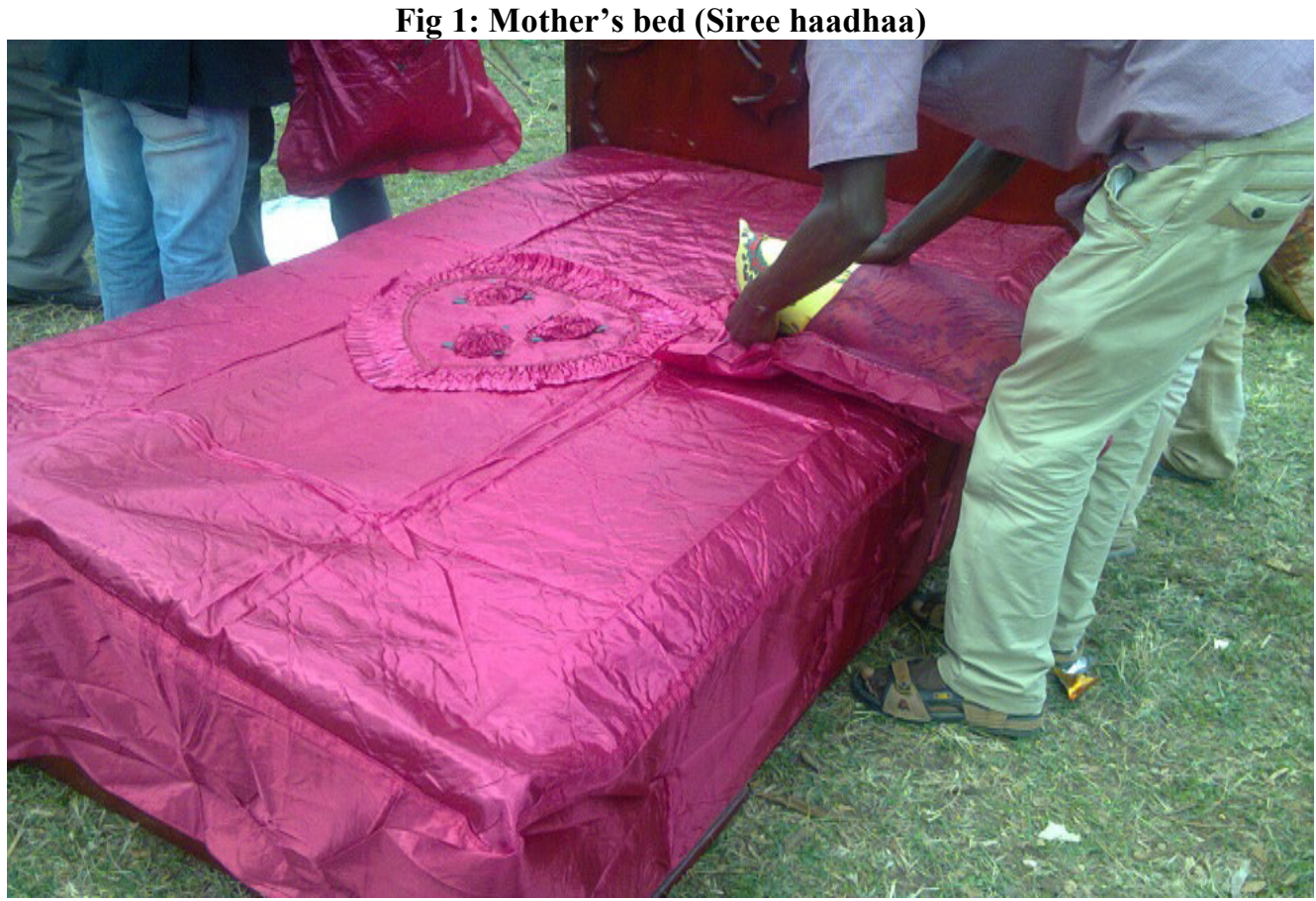

Source: From Researchers' fieldwork, May, 2017 G.C.

As one can understand from the above picture, it is a bed given by a groom for bride's mother. The bed is decorated with all materials as criteria. This habit is very popular in West Arsi zone.

Fig 2: Blankets and Other furnitures

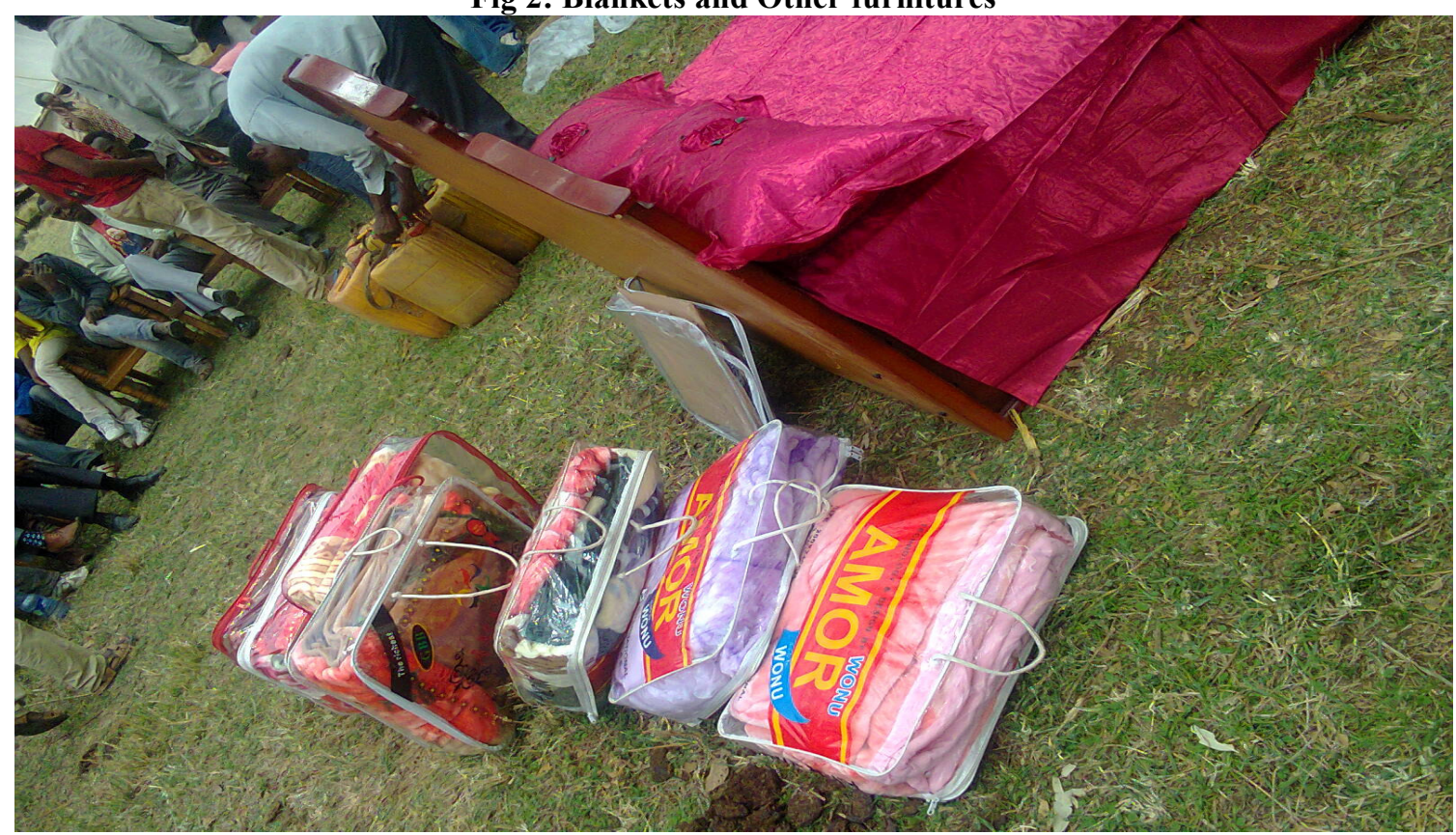

Source: From Researchers' observation of Gabbaraa marriage ceremony, May, 2017. 
Fig 3: Blanketing system (Sirna Uwwisa bullukkoo) on Wedding ceremony

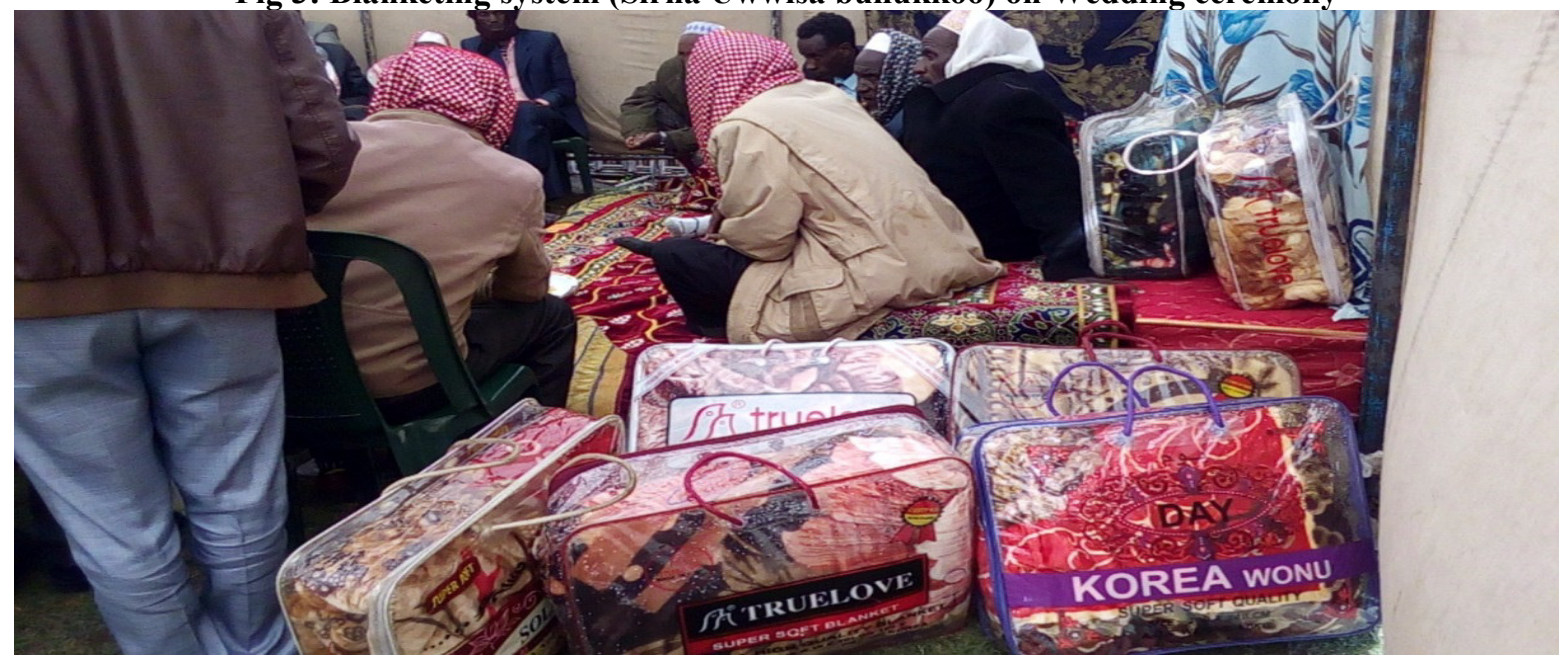

Source: From Researchers' observation of Gabbaraa marriage ceremony, 2018.

Elders observed from the above photo when they are clothing blankets (uwwisa bullukkoowwanii) gifted as dowry (Gabbaraa) for the proposed people. As analyzed under questionnaire and interview, the elders from family -in-law side come together and cloth people expected to be wore the provided blankets by bridegroom and his family one by one. The above photos also show this reality.

Fig 4: Heads of Cattle for dowry (Loon Gabbaraa)

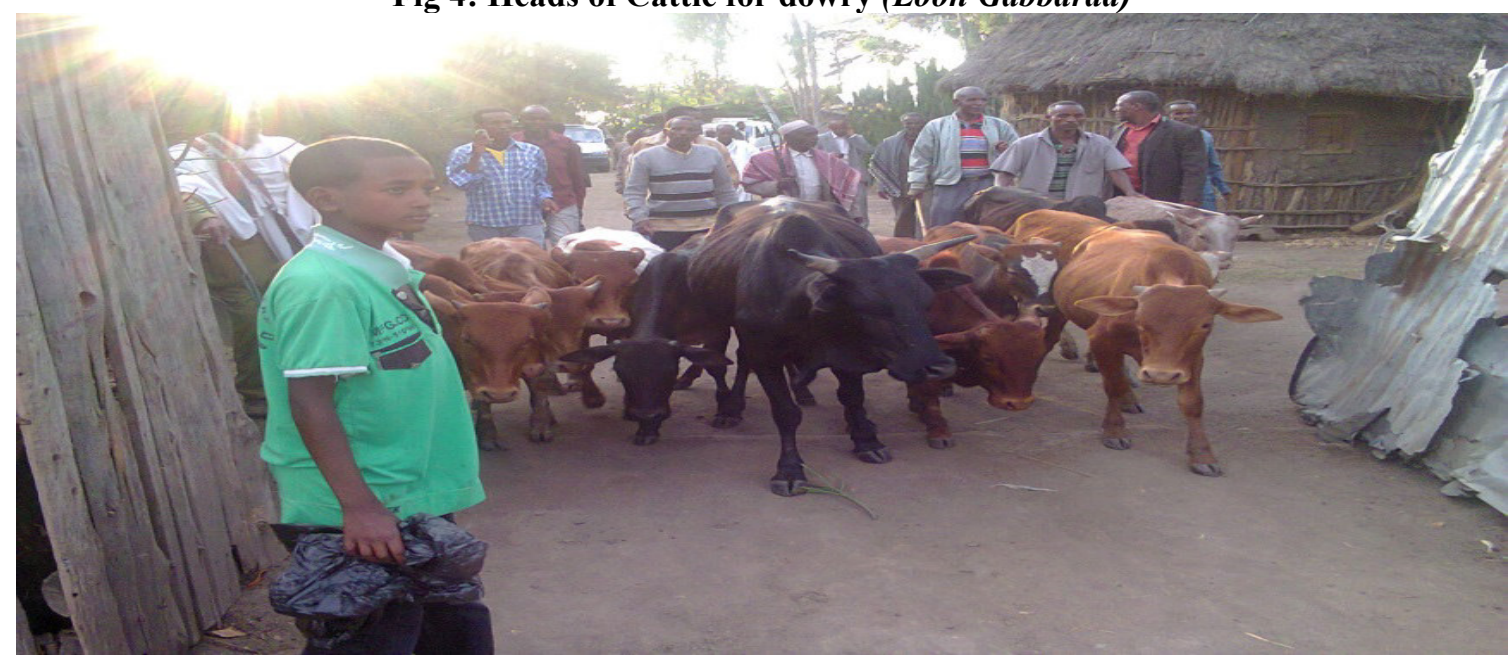

Source: From Researchers' observation of Gabbaraa marriage ceremony, May, 2017.

As can be understood from the above photo, these numbers of cattle are given for bride's family in a time only on a single Gabbara marriage ceremony. This reality is similar with the data gained though questionnaire and interview from respondents. Even though the number of cattle may not equal, some cattle are gifted as geegawoo (cattle gift by bride's family) and vice versa.

\section{Conclusions and Recommendations}

\subsection{Conclusions}

Conceptually, Gabbaraa means gifts provided by bridegroom or by his family or with their relatives for bride's family as a gift or support. Dowry (Gabbaraa) was started originally among Arsi Oromo by the gifts of only two cattle which were one heifer and bull (raadaa fi jibicha) and two blankets (wayaa lama) given for bride's family particularly for father's and mother's. These Gabbaraa were highly related to cultural sense and advocated mother-father (aayyaa-aabbaa) instance.

But now aday, it can be concluded that Gabbaraa marriage system has been being practiced with very high amount of dowry (Gabbaraa) over the others particularly in the selected woredas of West Arsi zone. Moreover, most of respondents have negative perceptions towards Gabbaraa marriage system. Forming family through Gabbaraa marriage with high dowry does not show the economic and social status of bride's and bridegroom's families in the society they are living with. This marriage system has challenges on couples and their families, and it has low role in decreasing the practices of bad traditional marriage like abduction, and depraved practices like adultery, unwanted preginancy, divorce, hesitation, bad relationship among relatives, family-in-law etc. 
Generally, Gabbaraa marriage is a marriage that is causing different challenges in the selected study areas. It has been imposing economic, social and psychological challenges on couples in particular and on societies as in general; and also it is creating phobia of marriage to most of youngsters due to the periodical increment of dowry (Gabbaraa) psychological aspects. In addition, it is creating disagreement between couples, bridegroom and his families -in-law, bride and her husband's family and between both families due to the raise of Gabbaraa in social aspects. As a result, people are developing dishonoring, disliking, disregarding and neglecting among them due to the increment of uncontrolled dowry (Gabbaraa) in this marriage system.

\subsection{Recommendations}

Depending on the summary and conclusions, the following major recommendations were made to the concerned bodies in order to put them into practice

- Awareness creation to wards Gabbara marriage challenges is expected from different concerned bodies; particularly, Culture and tourism offices of zonal and woredas should take their responsibilities with various stake holders.

- In in the dicision of dowry, bride's family and relatives should critically think at least for the future life of their daughter and consider social, economic and psychological perspectives in requesting maximum dowry since it can load a burden on bridegroom and his families and bride's family directly and indirectly.

- More than any other social classes, religious and Gada leaders and elders should offer advice and make discussion with communities on the increment of Gabbaraa and its challenges.

- Higher institutions in general and MWU in particular should discuss with the concerned bodies and work on the identified problems of surrounding societies related to Gabbaraa.

- In the practices of Gabbaraa marriage system, most peoples are following the footsteps of others and experiencing it more than other cultural marriage systems. Therefore, they should better perform their marriage in relation to indigenous culture.

- Society should give great consideration that youngsters are being exposed for adultery practice and illegal marriage which can increase divorce, sextually transmitted diseases, unwanted preginancy, health problems, social, economic and psychological risks on individuals in particular and society in general. Thus, society should give less attention for dowry and create available opportunities for their youngsters not to be exposed for these challenges.

- Different researchers should be expected to conduct more investigation issues related to this and others for depicting new philosophies of Oromo's people in indigenous cultural practices.

\section{References}

Abdul-Hai Al-Madni. (2012). Basic Countenance of Masculinity In The Light of Islam.

Amitai Etzioni \& Mackenzie Baris. (2005). A Communitarian Perspective on Sex and Sexuality. International Review of Sociology-Revue International de Sociologie Vol. 15, No. 2, July 2005, pp. 215-241.

Central Statistical Agency and the World Bank (CSA and World Bank). (2013): Ethiopia Rural Socioeconomic Survey (ERSS), Survey Report.

Cf. Relatio Synodi of the Third Extraordinary General Assembly of the Synod of Bishops: 'Pastoral Challenges of the Family in the Context of Evangelisation' (5-19 October 2014).

Denscombe, M. (2007). The Good Research Guide for small-scale social research projects $\left(3^{\text {rd }} \mathrm{Ed}\right.$.). New York, NY: Open University Press.

Fontana, L. \& Frey, J. H. (2005).The Interview: from neutral stance to political involvement. In N. K. Denzin \& Y. S. Lincoln (Ed.), The Sage Handbook of Qualitative Research. California: Sage.

Gemechu Beyene and Assefa Tolera. (2006). Marriage Practices Among the Gidda Oromo, Northern Wollega, Ethiopia. Tuskegee University, Alabama, U.S.A and Addis Ababa University, Ethiopia. Nordic Journal of African Studies 15(3): 240-255.

Husseen Badhaasoo .(2000). Seera Fuudhaa fi Heeruma Arsii. Finfinnee International Encyclopedia of the Social Sciences (1977)

Kothari, C.R. (2004). Research Methodology. Methods and Techniques. $\left(2^{\text {nd }}.\right)$.

Leila Qashu . (2009).Arsi Oromo Society Viewed Through Its Wedding Music. Proceedings of the 16th International Conference of Ethiopian Studies, ed. by Svein Ege, Harald Aspen, Birhanu Teferra and Shiferaw Bekele, Trondheim 2009.

Maammoo Gadaa. (2013). Duudhaa. (Kutaa 2ffaa). Barruu Amantii, Safuu fi Aadaa Duudhaa Oromoo irratti xiyyeeffate. Finfinnee.

Riker, A. Palm \& Brisbane, Holly. E. (1997). Married and Single Life. (6 ${ }^{\text {th }}$ Ed.). Glencoe: McGraw-Hill 